Pregledni članak UDK 159.947(045)

doi: $10.21464 /$ fi38210

Primljeno: 15. 9. 2017.

\author{
Matija Lukač \\ Psihijatrijska bolnica Rab, Kampor 224, HR-51280 Kampor \\ lukacmatija@gmail.com
}

\title{
Kolektivna intencionalnost kao mehanizam
}

\begin{abstract}
Sažetak
Rad nastoji istražiti je li kolektivna intencionalnost potencijalno mehanizam te može li biti okarakterizirana jednim od dva temeljna mehanicistička pristupa: Glennanovim konceptom i/ili MDC konceptom. Rad ne pruža odgovor na debatu o prirodi kolektivne intencionalnosti, nego nastoji podcrtati što filozofi iz nje mogu naučiti. Čitanje i interpretacija u ovom radu nije posve slična Cohenovu razumijevanju intencionalnosti. Naime, dok Cohen smatra da je kolektivna intencionalnost u potpunosti svediva na individualnu intencionalnost, ovaj je rad više epistemološko pitanje ispravnosti definiranja kolektivne intencionalnosti kao mehanizma. Prvi dio rada odnosi se na definiranje uloge same debate o kolektivnoj intencionalnosti. Uzimaju se u obzir epistemološka i socijalno-ontološka pozicija definiranja uloge kolektivne intencionalnosti, njezino objašnjenje, metode istraživanja, kao i argumentiranje da obje analize nailaze na sličan problem (nesvodivost kolektivne intencionalnosti na individualnu intencionalnost). $U$ drugom se dijelu razmatra uloga ove debate $i$ što iz nje možemo naučiti. Točnije, nastoji se istražiti posjeduje li kolektivna intencionalnost potencijal mehanizma, odnosno može li je se okarakterizirati kao mehanizam, rukovodeći se konceptom mehanizma nove mehanicističke filozofije.
\end{abstract}

\section{Ključne riječi}

Laurence Jonathan Cohen, intencionalnost, kolektivna intencionalnost, mehanizam, nova mehanicistička filozofija

\section{Uvod}

Kolektivna intencionalnost je višeznačan pojam. Ponekad označava karakteristiku svakodnevne lingvističke upotrebe, pa, primjerice, ako ja nešto radim i ti nešto radiš, tada mi nešto radimo (Searle, 2010: 49). Suprotno tome, može referirati na zajedničko znanje, zajedničku posvećenost s ciljem ostvarenja nekog zajedničkog cilja (Searle, 2010: 49), zajedničko prihvaćanje (Gilbert i Pilchman, 2014: 202), dispoziciju pojedinca da osjeća ispravnost pojedine premise i temeljem toga rješava problem (Gilbert i Pilchman, 2014: 190-192) ili, pak, kolektivno vjerovanje (Gilbert i Pilchman, 2014). Sam Searle tumači kolektivnu intencionalnost kao sposobnost ljudi i drugih životinja da surađuju u svojim aktivnostima, pri čemu kooperacija implicira postojanje zajedničkog znanja ili vjerovanja, ali samo zajedničko znanje ili vjerovanje u suradnji s individualnim intencijama u svrhu ostvarenja zajedničkog cilja nedovoljne su za ostvarenje kooperacije (Searle, 2010: 49). Drugo je, signifikantno uporište deskripcije i askripcije kolektivne intencionalnosti kod brojnih autora analiza njezine pojavnosti kod odraslih pojedinaca koji se služe jezikom. Svakako se radi o razboritoj pretpostavci, prvenstveno za većinu teorijskih promišljanja i analiza, međutim, ovdje prihvaćam Searleovu tvrdnju kako se ne radi o te- 
meljnom konceptu analize ljudskog društva jer, naime, ono pretpostavlja postojanje jezika, a postojanje jezika već podrazumijeva egzistenciju ljudskog društva (Searle, 2010).

Ovaj rad nastoji istražiti može li kolektivna intencionalnost - kao višeznačan pojam - biti adekvatno okarakterizirana stajalištem nove mehanicističke filozofije. Točnije, brojna recentna literatura o mehanizmima apostrofira superiornost mehanicističkog objašnjenja zakona i nomoloških objašnjenja paradigmatskih mehanizama, ukazujući pri tome na njihov stabilitet ponašanja i funkcioniranja (Glennan, 2010: 251). Premda su ovakvi mehanizmi i objašnjenja od velikog značaja, brojni događaji i njihova pojavnost ne uspijevaju biti objašnjeni modusom stabilnog mehanizma na koji referira nova mehanicistička filozofija. Potaknuto ovom idejom, tendencija je ovog rada nastojanje da se propita priroda fenomena kolektivne intencionalnosti, odnosno posjedovanje potencijala mehanizma s ciljem pružanja jasnije deskripcije i atribucije fenomena kolektivne intencionalnosti. U ovom se radu nastoji istaknuti da, usprkos tome što kolektivna intencionalnost ne uspijeva zadovoljiti zadane kriterije stabilnog mehanizma, ovaj proces zaslužuje da ga se opisuje kao mehanizam.

Ono što se smatra novom mehanicističkom filozofijom zapravo obuhvaća dva temeljna koncepta mehanizma, naime Glennanov koncept mehanizma i onaj Machamera, Dardena i Cravera (MDC) (Skipper Jr. i Millstein, 2005: 327). Cilj je nove mehanicističke filozofije izgradnja filozofskog okvira za razumijevanje prirode i uloge mehanizama u znanosti (Skipper Jr. i Millstein, 2005: 328). Svrha je ovog rada nastojanje da se utvrdi može li kolektivna intencionalnost biti adekvatno zahvaćena i opisana unutar tog okvira.

\section{Kolektivna intencionalnost}

Centralno je pitanje rada pitanje kolektivne intencionalnosti. Onaj tko u srž svojeg argumenta pozicionira da svi ili većina članova grupe posjeduje vjerovanje koje je pripisano grupi naziva se sumativistom. Takav sumativist, recimo, poriče da grupa posjeduje vjerovanje, emocije, stavove te smatra da se radi o pukom metaforičkom govoru ${ }^{1}$ (Gilbert i Pilchman, 2014). Interpretirano na ovaj način, askripcija mentalnih predikata grupi predstavlja indirektnu atribuciju tih predikata njezinim članovima (Gilbert i Pilchman, 2014). Jonathan L. Cohen se u svojem radu An Essay on Belief and Acceptance (Cohen, 1995) bavi onime što naziva vjerovanje grupe. Naime, za Cohena vjerovati znači da $\gg P$ predstavlja dispoziciju, temeljem koje pojedinac nastoji riješiti proizašli problem, propozicijom $\mathrm{P}$, gdje osjeća da $\mathrm{P}$ je istinito, a ne-P lažno« (Cohen, 1995: 4). Drugim riječima, Cohen veže sposobnost vjerovanja uz osjećaje, za razliku od prihvaćanja:

»Prihvatiti da P podrazumijeva ubrajanje propozicije da $\mathrm{P}$ u nečije premise odlučivanja, bez obzira osjeća li pojedinac istinitost propozicije da P.«(Cohen, 1995: 4)

Iz spomenutog slijedi da grupe ne mogu osjećati ili biti izložene osjećanju. Unatoč vlastitoj skeptičnosti o egzistiranju kolektivnog vjerovanja, Cohen je svjestan prevalencije svakodnevne atribucije kolektivnom vjerovanju te smatra da:

».. kada grupa ili nacija tvrdi da vjeruje da P ili teži da $\mathrm{P}$, to je naprosto figurativan način da se kaže da većina individua ili veliki dio njih vjeruje ili teži da P.« (Cohen, 1995)

Iz ovog slijedi da grupa $G$ vjeruje da $P$ ako i samo ako svi ili većina njih vjeruje da P. Drugim riječima, grupna vjerovanja u potpunosti su svediva na indi- 
vidualna vjerovanja te ovdje govorimo o tzv. redukcionizmu. Unatoč tome što Cohen iznosi početno primamljive dokaze za svoj skeptični zaključak, njegov je zaključak radikalan po svom dosegu i snazi. Sam Cohenov rad polučio je brojne kritike, a svakako najznačajnije su one Raimoa Toumelae (Toumela, 2000: 128) i Leslieja Stevensona (Stevenson, 2002: 111) u kojima se ističe kako osjećaj vjerovanja uopće nije osjećaj, kako inicijalno tvrdi Cohen. Stoga se Cohenovo stajalište doima primamljivim, a isprva čak i intuitivno uvjerljivim jer se svaki korak u dokazu čini ispravnim. To je u suštini ono što Cohenovu epistemološku poziciju čini zanimljivom jer nas suočava sa smjerom zaključivanja koji mi sami nalazimo intuitivno uvjerljivim, ali koji vodi do zaključka koji držimo apsolutno neuvjerljivim.

Suprotno od Cohena, John Searle u svojem radu The Social Construction of Reality propituje prirodu kolektivne intencionalnosti (Searle, 2010: 42-61). Prema Searleu, veliki broj životinja, ali i ljudi posjeduje mogućnost dijeljenja intencionalnih stanja kao što su vjerovanja, želje i intencije (Searl, 1995: 1-31). Jedno od najznačajnih pitanja koje Searle postavlja u djelu The Social Construction of Reality je svakako pitanje relacije individualne i kolektivne intencionalnosti. Naime, on smatra da kolektivna intencionalnost predstavlja primitivan biološki fenomen koji nije svediv ni na što drugo (Searle, 2010: 42-61). Točnije, ni jedan set Ja svjesnosti, pa čak ni najsloženiji, ne može tvoriti kolektivnu svjesnost. Prema tome, kolektivna intencionalnost predstavlja smisao za raditi (željeti, vjerovati itd.) nešto zajednički, dok individualna intencionalnost koju posjeduje pojedinac proizlazi iz kolektivne intencionalnosti koju članovi grupe dijele (Searl, 1995). Drugim riječima, bilo koji pokušaj ili redukcija kolektivne intencionalnosti na individualnu intencionalnost je pogrešna. Searleova je vlastita dijagnoza spomenute relacije da sva intencionalnost mora egzistirati u mozgu individue, međutim to ne implicira da je Mi-intencionalnost svediva, reducibilna na Ja-intencionalnost (Searle, 2010: 50-55). Osim toga, Searle pretpostavlja tzv. metodološki individualizam, ${ }^{3}$ iz čega slijedi da »ako mi čistimo zajedno dvorište, tada u mojoj glavi perzistira misao 'mi čistimo dvorište', a u tvojoj glavi egzistira misao 'mi čistimo dvorište' " (Searle, 2010: 49). Uzmemo li u obzir ovaj oblik argumentacije, tada Searle predstavlja antiredukcionističku struju u čijoj se pozadini nalazi pojedinac kao osnovni tvorbeni element kolektivne intencionalnosti. Kolektivna intencionalnost nije svediva na individualnu intencionalnost, ali jednako tako ne možemo govoriti o egzistenciji pluralnog subjekta jer za Searlea to nije prihvatljivo.

Suprotno Searleu, Margaret Gilbert razmatra epistemološko rješenje problema kolektivne intencionalnosti. Riječ je o ideji da se istraži konstitutivnost kolek-

Sumativizam u središte svoje ideje pozicionira stav da svi ili većina članova grupe posjeduje vjerovanje koje se pripisuje grupi. Jedan od glavnih pobornika ove ideje je Jonathan L. Cohen, a svoju tezu izlaže u djelu An Essay on Belief and Acceptance. Ideju sličnu Cohenovoj zastupa Anthony Quinton i to čak nekoliko godina prije Cohena (Gilbert i Pilchman, 2014: 194)

Cohenov rad An Essay on Belief and Acceptance rezultirao je brojnim polemikama, kritikama te u konačnici i odbacivanjem. Primjerice, Toumela smatra da je osjećaj vjerovanja kod Cohena nešto više od vjerovanja da je neki sadržaj istinit. Točnije, tzv. osjećaj vjerovanja nije uopće osjećaj. Suprotno od Cohenova vjerovanja, Stevens smatra da pozivanje na osjećaj vjerovanja u konačnici uopće nije oblik vjerovanja.

3

Metodološki je individualizam teorijski pristup koji tumačenje društvenih pojava svodi na pojedince i njihova svojstva. Vidi: »Metodološki individualizam«, Struna, Institut za hrvatski jezik i jezikoslovlje. Dostupno na: http:// struna.ihjj.hr/naziv/metodoloski-individualizam/21093/ (pristupljeno 15. veljače 2018.). 
tivne intencionalnosti. Gilbert propituje sumativističku kritiku kolektivne intencionalnosti i ocjenjuje ju pogubnom. Jedan od prigovora je taj da »ukoliko grupa $\mathrm{G}$ vjeruje da $\mathrm{P}$ bez da ijedan član vjeruje da $\mathrm{P}$, utoliko sumativizam bez obzira na stupanj kompleksnosti nije istinit« (Gilbert i Pilchman, 2014: 196). Primjerice, Marko na ulici susreće Ivanu te u nastojanju da kaže nešto lijepo prozbori »Predivan dan, zar ne?«. U nastojanju da potvrdno odgovori Ivana kaže »Da, doista!«. U međuvremenu, Marko i Ivana susreću Petra koji gunđa o današnjem danu i vremenu. Ivana puna samopouzdanja u Markovo i svoje ime odgovara Petru »Mi smatramo da je dan predivan. «. Glavna strategija koju Gilbert nudi je tzv. joint commitment za koji vrijedi da: »članovi populacije $\mathrm{P}$, kolektivno vjeruju da $\mathrm{P}$ ako i samo ako su se zajednički posvetili tome da kao tijelo vjeruju da $\mathrm{P}$ « (Gilbert i Pilchman, 2014: 197). Drugim riječima, kolektivna intencionalnost predstavlja fenomen kolektivnog vjerovanja.

Ovdje se valja dotaknuti Wrayjeve argumentacije. On nam, naime, kaže da argument za njegovu verziju opravdanja kolektivne intencionalnosti pretpostavlja veliki dio modela Margaret Gilbert. Kao i u njezinom modelu, riječ je otprilike o zamisli da kolektivna intencionalnost predstavlja fenomen, ali ne fenomen kolektivnog vjerovanja, nego kolektivnog prihvaćanja ${ }^{4}$ (Wray, 2001: 319). Gilbert odbacuje takvu interpretaciju kolektivnog vjerovanja te naglašava u svojem djelu Belief and Acceptance as Features of Groups da kolektivno vjerovanje nije prihvaćanje, kako to tvrde pobornici pozicije odbijanja (Gilbert, 2002: 35-69). Svoje stajalište brani iznoseći primjere kojima nastoji pokazati oprečnost pozicije odbijanja. ${ }^{5}$

Napokon, bit će korisno usporediti Searleov odgovor na problem kolektivne intencionalnosti s onime što brani Gilbert. Čini se očitim da su njih dvoje u sporu jer Gilbert prihvaća mogućnost postojanja pluralnog subjekta, dok za Searlea to nije moguće. Međutim, obratimo li veću pozornost na njihovu terminologiju, možemo uočiti dvije važne točke slaganja. Kao prvo, Searle poima kolektivno vjerovanje kao rudimentaran fenomen koji nije nužno uvjetovan i svediv na individualna vjerovanja te tako napušta redukcionističku analizu kolektivne intencionalnosti. Epistemološka alternativa koju iznosi Gilbert jednako tako odbacuje ovo viđenje. Drugo, i Gilbert i Searle smatraju da je sumativizam neodrživ i neprihvatljiv za objašnjavanje kolektivnog vjerovanja. Ono u čemu se ne slažu je prihvaćanje postojanja pluralnog subjekta. Naime, za Gilbert to je više nego moguće, međutim sam Searle odbacuje ovu ideju te smatra kako je pojedinac osnovni tvorbeni element kolektivne intencionalnosti.

U nastavku rada bavit ću se pitanjem mehanizama, točnije posjeduje li kolektivna intencionalnost potencijal mehanizma te može li biti adekvatno okarakterizirana unutar okvira nove mehanicističke filozofije. Drugim riječima, nastoji se istražiti mogućnost primjene mehanicističke teorije i njezinih alata na fenomen kolektivne intencionalnosti. Ranije sam spomenuo i opisao dva prominentna pravca argumentacije o prirodi kolektivne intencionalnosti, epistemološku i socijalno-ontološku poziciju. Uvidjeli smo da postoje sličnosti i razlike u njihovom poimanju. Znanstvena utemeljenost i opravdanost (ne)egzistencije kolektivne intencionalnosti tema je brojnih diskusija unutar epistemologije, ontologije i socijalne ontologije. Osnovni problem koji se razmatra u ovim raspravama jest reflektira li kolektivna intencionalnost na egzistenciju tzv. pluralnog subjekta ili ne, odnosno možemo li i smijemo li reducirati kolektivnu intencionalnost na individuu kao osnovnu tvorbenu jedinicu. Konstrukt kolektivne intencionalnosti u kontekstu spomenute rasprave (epistemologije i socijalne ontologije) posebno je interesantan jer navede- 
na dijagnoza podrazumijeva značajne društvene posljedice. Točnije, s jedne strane, za Searlea je to polazište formiranja socijalnih sistema, tj. osnivanje socijalnih institucija (Searl, 1995), dok je, s druge strane, za Gilbert to argument koji apostrofira potrebitost formiranja nove, generičke epistemologije koja će pružiti jasniji uvid i analizu zbivanja unutar tabora kolektivne epistemologije (Gilbert i Pilchman, 2014: 209). Vodeći se recentnim raspravama o problemu kolektivne intencionalnosti na epistemološkom horizontu, oslanjam se na ideju kolektivnog vjerovanja te je nastojim sagledati kroz prizmu nove mehanicističke filozofije. Posljedično, nastojat će se ugraditi ideju joint commitmenta $\mathrm{u}$ formulu nove mehanicističke filozofije te uvidjeti možemo li i smijemo li govoriti o kolektivnoj intencionalnosti kao mehanizmu. Drugim riječima, posjeduje li kolektivna intencionalnost potencijal mehanizma ili ne. Valja napomenuti da se u uvodnom dijelu razmatra i socio-ontološka dimenzija viđenja kolektivne intencionalnosti, međutim ona nije relevantna za spomenutu konverziju. Stoga aspiracija ovog rada nije pružanje uniformnog odgovora na pitanje kolektivne intencionalnosti, nego nastojanje da se istraži je li moguće govoriti o kolektivnoj intencionalnosti u epistemološkom smislu kao mehanizmu. Je li koncept kolektivnog vjerovanja u stanju ponuditi relevantne dokaze temeljem kojih možemo zaključiti da kolektivna intencionalnost posjeduje mehanicistički potencijal?

U članku će se razmotriti mehanicistička gledišta koja ističu potrebne uvjete da bi neki skup osobina (u ovom slučaju kolektivna intencionalnost), koji se pojavljuje zajedno kod određenih pojedinaca, bio znanstveno stabilan (Skipper Jr. i Millstein, 2005), ali i gledišta koja izražavaju sumnju u utemeljenost kolektivne intencionalnosti kao stabilnog mehanizma. Iz epistemološke perspektive, debata o kolektivnoj intencionalnosti je vrlo interesantna, kako unutar individualne, tako i u kontekstu kolektivne epistemologije (Gilbert i Pilchman, 2014: 190). Navedeno pitanje o prevođenju kolektivne intencionalnosti kao mehanizma do sada nije u prevelikoj mjeri bilo fokus filozofske rasprave te se može navesti mali broj radova koji ga se djelomično dotiču (Ferraris, 2015). Generalni problem koji se bavi mogućnošću specificiranja koji kriteriji moraju biti ispunjeni da bismo neku pojavnost smatrali mehanizmom je $\mathrm{u}$ filozofiji biologije vrlo zastupljen $\mathrm{u}$ formi rasprave »o prirodi prirodne selekcije« (eng. natural selection) (Brunnander, 2007; Matthews, 2016; Skipper Jr. i Millstein, 2005; Glennan, 2010). Rasprava se vodi o tome što neku pojavnost čini mehanizmom te korespondira li ona s teorijskim okvirom nove mehancističke filozofije. U ovom se radu zauzima epistemološko viđenje kolektivne intencionalnosti iako je pitanje eksplanatorne važnosti kolektivne intencionalnosti jednako zanimljivo bez obzira koju poziciju zauzeli. S obzirom na to da epistemološko viđenje kolektivne intencionalnosti podrazumijeva široko poimanje i klasifikaciju kolektivne

Jedna od kolaterala modela Margaret Gilbert je pozicija odbijanja. Pobornici ove pozicije smatraju da model koji zagovara Gilbert jest ispravan te da opisuje realan fenomen, ali to nije fenomen vjerovanja, nego fenomen prihvaćanja. Oni odbacuju ideju kolektivnog vjerovanja te smatraju da kolektivno vjerovanje nije vjerovanje, nego prihvaćanje. Naime pozicija odbijanja odobrava i postulira viđenje Wrayja u kojem on ističe da pitanje kojim se Gilbert bavi nije pitanje vjerovanja, nego pitanje prihvaćanja (Wray, 2001: 202-205).
Gilbert nastoji prikazati oprečnost pozicije odbijanja na način da se usredotočuje na njihovu tvrdnju o volji za prihvaćanjem, a suprotnost je vjerovanju. Prema poziciji odbijanja, vjerovanje ne može biti voljno. Točnije, ne mogu prizvati vlastito vjerovanje bilo aktom volje bilo neizravno. Za razliku od vjerovanja, prihvaćanje je direktno voljno; u nastojanju da prihvatim neku propoziciju, ja je moram izravno željeti prihvatiti. Za detaljniji opis ove diskusije vidi: (Meijers, 1999: 59-73); (Gilbert i Pilchman, 2014: 202-207). 
intencionalnosti, prihvaća se ideja Margaret Gilbert (Gilbert i Pilchman, 2014). Također, zastupa se gledište kolektivne intencionalnosti kroz prizmu joint commitmenta, nastoji ga se analizirati alatom nove mehanicističke filozofije te posljedično utvrditi posjeduje li kolektivna intencionalnost potencijal mehanizma.

\section{Nova mehanicistička filozofija}

Problematiziranje nove mehanicističke filozofije podrazumijeva dvije osnovne koncepcije mehanicističke reprezentacije, Glennanovu koncepciju mehanizma i onu Machamera, Dardena i Cravera (MDC) (Skipper Jr. i Millstein, 2005: 327-328). Za Glennana je mehanizam kompleksni sistem čiji su dijelovi međusobno u interakciji i proizvode ponašanje (Glennan, 1996: 52). Takve mehanizme on naziva stvarima, pri čemu se referira na kompleksni sistem:

»Složeni sistem-mehanizmi su stvari (ili objekti).«(Glennan, 2002b: 344)

Glennan je modificirao svoju izvornu definiciju mehanizma tijekom vremena, a recentna glasi:

»Mehanizam ponašanja je kompleksni sistem koji proizvodi to ponašanje interakcijom njegovih brojnih dijelova, pri čemu interakcija između dijelova može biti okarakterizirana kao direktna, invarijantna, promjenom zavisna generalizacija.«(Glennan, 2002b: 344)

Da bi pojasnio svoju definiciju i poimanje mehanizma, Glennan koristi primjer toaleta, sistema čiji su dijelovi povezani i međusobno djeluju u nastojanju da se nadoknadi rasipanje vode. Jednako tako u biologiji možemo vidjeti brojne primjere mehanizama koji udovoljavaju Glennanovoj deskripciji. Primjerice srce, odnosno krvožilni sustav čiji dijelovi međusobno interaktiraju s ciljem pumpanja krvi (Skipper Jr. i Millstein, 2005: 332). Ovdje valja dotaknuti još jedan vid Glennanove argumentacije. On, naime, razlikuje tzv. sistem-mehanizam i proces-mehanizam, pri čemu prvi označava jedinstveni lanac događaja koji je jedinstvena sekvenca mogućih međusobno povezanih događaja proizvoljne složenosti (Glennan, 2002: 128). Da bi objasnio ovu definiciju mehanizma, koristi primjer izbijanja Prvog svjetskog rata, naime, koji je to mehanizam koji je doveo do izbijanja prvog svjetskog rata? Za Glennana, ovaj upit zahtijeva detekciju uzročne veze u kojoj jedan određeni događaj, u ovom slučaju ubojstvo nadvojvode Ferdinanda, može biti okarakterizirano kao događaj koji je rezultirao drugim određenim događajem, tj. izbijanjem Prvog svjetskog rata (Skipper Jr. i Millstein, 2005: 332). Nadalje, Glennan u svojoj distinkciji proces-mehanizma od sistem-mehanizma ne govori ništa o njegovoj konstitutivnosti. Uglavnom, deskripciju proces-mehanizma svodi na konstataciju što ono nije. Kao razlog tome, Glennan smatra da proces-mehanizmi nisu dovoljno stabilni u produkciji ponašanja te ne posjeduju stabilnu dispoziciju koja bi rezultirala vlastitom pojavnosti (Skipper Jr. i Millstein, 2005: 333; Glennan, 2002b: 345). Glennan se posljedično okreće sistem-mehanizmima. Prema tom stajalištu, Glennan smatra da je upravo interakcija u sistem-mehanizmu kardinalna stavka koja objašnjava što povezuje dijelove mehanizma koji onda rezultira promjenom od početka do kraja svog lanca (Skipper Jr. i Millstein, 2005: 333). Iz ovog slijedi da je interakcija događaj u kojem promjena svojstva jednog dijela rezultira promjenom svojstva drugog dijela mehanizma (Skipper Jr. i Millstein, 2005: 333; Glennan, 2002b: 344). Nadalje, Glennan ističe kako proces-mehanizmi mogu uključivati sistem- 
mehanizme, ali oni sami po sebi nisu mehanizmi. Naturalizirana alternativa ovom pristupu je ona Machamera, Dardena i Cravera (MDC):

»Mehanizmi su entiteti i aktivnosti organizirane na način da su produktivne i regularne promjene od početka ili namještanja pa sve do kraja ili prekida postojanja uvjeta." (Machamer i dr., 2000:3, Skipper Jr. i Millstein, 2005: 333)

U nastojanju da potkrijepe vlastitu definiciju mehanizma, Machamer i suradnici koriste primjer neuralne depolarizacije i sinteze proteina (Darden i Craver, 2002; Skipper Jr. i Millstein, 2005: 333). Točnije, aktivnosti u mehanizmu proizvode promjenu, a entiteti su ti koji su u njih involvirani. Pojavnost specifičnih aktivnosti zahtijeva da ti entiteti posjeduju određena relevantna svojstva, primjerice elektrokemijska, elektromagnetska svojstva itd. (Skipper Jr. i Millstein, 2005). Nadalje, entiteti za MDC često moraju biti adekvatno pozicionirani, strukturirani i orijentirani, a aktivnosti u koje su involvirani moraju imati temporalni redoslijed, vrijeme, trajanje (Machamer i dr., 2000: 3; Skipper Jr. i Millstein, 2005: 333). Upravo taj kontinuitet osigurava regularne i produktivne promjene u mehanizmu.

Kako je pokazano, postoje tri ključne razlike između spomenuta dva koncepta mehanizma. Glennan eksplicitno govori o distinkciji proces-mehanizma i sistem-mehanizma, pri čemu središte njegove analize predstavlja sistem-mehanizam. MDC nude jednoznačan koncept mehanizma. Drugo, Glennan se primarno oslanja na interakciju u nastojanju objašnjenja produktivnog kontinuiteta mehanizma, dok MDC odbacuju tu ideju te nude dualističku perspektivu u nastojanju da riješi pitanje produktivnog kontinuiteta mehanizma. Treće, Glennan se služi idejom direktne, invarijantne, promjenom zavisne generalizacije s ciljem objašnjenja regularnosti mehanizma, dok MDC smatraju da je mehanizam regularan utoliko ukoliko funkcionira uvijek ili u većini slučajeva na isti način u istim uvjetima (Skipper Jr. i Millstein, 2005: 334).

\section{Glennan, MDC i kolektivna intencionalnost}

U ovom poglavlju nastojat ću istražiti i argumentirati kako kolektivna intencionalnost nije organizirana na način na koji smatraju Glennan i MDC, odnosno ni jedan od spomenuta dva koncepta mehanizma ne uspijeva zahvatiti produktivni kontinuitet kolektivne intencionalnosti. Točnije, ni Glennanov princip interakcije ni ideja entiteta i njihove aktivnosti koju su predložili MDC ne nudi odgovor na pitanje produktivnog kontinuiteta ovog mehanizma, niti je kolektivna intencionalnost regularan mehanizam, kako to smatra MDC koncept.

Prethodna rasprava o prirodi mehanicističke filozofije usmjerila nas je na dva temeljna koncepta mehanizma, Glennanov koncept i MDC koncept. Nadalje, uvidjeli smo da Glennan razlikuje proces-mehanizam i sistem-mehanizam, dok MDC koncept nudi uniformnu definiciju mehanizma. Nadalje, MDC koncept zahvaća prirodu mehanizama u molekularnoj biologiji i neurobiologiji te bi kao takav možda mogao ostvariti aplikabilnost i u drugim znanstvenim područjima. No je li to doista tako? Unatoč razboritom pokušaju MDC koncepta o aplikabilnosti ovog modela na prirodu ostalih mehanizama u znanosti, čini se kako ni MDC ni Glennanov koncept mehanizma ne uspijevaju na adekvatan način zahvatiti prirodu kolektivne intencionalnosti. Točnije, ne uspijevaju odgovoriti na pitanje organizacije, produktivnog kontinuiteta i regularnosti te, posljedično, ne nude adekvatan opis mehanicističke reprezentacije kolektivne intencionalnosti. 


\section{Organizacija}

Tvrdnja »mehanizmi su organizirani« implicira: 1) da su mehanizmi sastavljeni od različitih elemenata i 2) da su ti elementi strukturirani na neki određeni način (Skipper Jr. i Millstein, 2005). Kao što smo vidjeli u prethodnoj raspravi, Glennan je nejasan u vlastitom razumijevanju sistem-meahanizma jer tretira sistem kao sinonim za objekt ili stvar. Štoviše, njegovo viđenje mehanizma je ono »kompleksnog sistema sastavljenog od mnoštvo dijelova, a ti dijelovi interaktiraju na određeni, pouzdani način te proizvode dano ponašanje « (Glennan, 1996: 52, usp. Skipper Jr. i Millstein, 2005: 336). Je li kolektivna intencionalnost takav mehanizam? Možemo li svesti kolektivnu intencionalnost na njezine dijelove? Što bi bili ti dijelovi? Bi li bili organizmi, prihvaćanje ili vjerovanje? Ukoliko kolektivna intencionalnost može biti shvaćena pomoću dijelova, utoliko neće biti način koji zagovara Glennan, točnije njegov model toaleta. Sljedeći aspekt Glenannove mehanicističke reprezentacije je da je mehanizam kompleksni sistem sastavljen od »dijelova«. Međutim, njegova definicija konstitutivnosti dijelova mijenjala se s vremenom. Ona recentna je da: »svojstva nekog dijela moraju biti stabilna u odsutnosti intervencija, ili kompleks objekata mora tvoriti stabilnu konfiguraciju da bi mogao biti okarakteriziran kao objekt « (Skipper Jr. i Millstein, 2005: 336). Točnije, dijelovi mogu općenito biti prostorno lokalizirani, a njihova insercija, što je ponašanje mehanizma, je set dispozicija koji posjeduje mehanizam temeljem te uređenosti i međusobne povezanosti dijelova (Glennan, 2002b: 126-127). Drugim riječima, njegovo poimanje dijelova mehanizma je striktno fizičko. Stoga se postavlja pitanje možemo li opisati dijelove kolektivne intencionalnosti na način koji to nudi Glennan? Jedna od mogućih pretpostavki je da individue i kooperacija jesu dijelovi. Ukoliko kooperacija posjeduje stabilna svojstva kao što zahtijeva Glennan, utoliko je pitanje koje se nameće sljedeće: je li kooperacija jedan dio ili više njih? Ako predstavlja više njih, koliko točno? Smatramo li prihvaćanje dijelom? Je li vjerovanje još jedan dio? Ukratko, nije posve razumljivo na koji je način u Glennanovoj mehanicističkoj reprezentaciji mehanizam konstituiran od svojih dijelova.

Prikaz što ga brane Machamer i suradnici (MDC) je eksplicitniji što se tiče elemenata mehanizma. Njihovo je viđenje mehanizma kao entiteta i njihove aktivnosti. Prisjetimo li se MDC gledišta, uviđamo da za ovaj model entiteti često moraju biti adekvatno pozicionirani, strukturirani i orijentirani, a aktivnosti u koje su entiteti involvirani moraju imati vremenski redoslijed i trajanje (Machamer i dr., 2000: 3, Skipper Jr. i Millstein, 2005: 337). Stoga, pregled standardne mehanicističke prakse Glennanova modela i onog MDC-a otkriva da ni jedan od dva spomenuta ne uspijeva adekvatno zahvatiti i opisati organizaciju mehanizma kolektivne intencionalnosti. Štoviše, ova dva koncepta poimaju kolektivnu intencionalnost kao stabilan, robustan i repetitivan mehanizam, a ona to u konačnici nije. Prema tome, ni MDC ni Glennanov koncept mehanizma ne uspijevaju odgovoriti na pitanje organizacije kolektivne intencionalnosti.

\section{Produktivni kontinuitet}

Sljedeći zahtjev na koji bi odgovor trebala dati dva prethodno spomenuta koncepta pitanje je produktivnog kontinuiteta. Srž Glennanove argumentacije tvori interakcija između dijelova mehanizma. Točnije, interakcija između dijelova mehanizma je ta koja omogućava solidnost ponašanja, a posljedično 
dijelovi mehanizma generiraju dano ponašanje (Glennan, 2002b: 344; usp. Skipper Jr. i Millstein, 2005: 339). Dakle, interakcija je događaj u kojem promjena svojstva jednog dijela dovodi do promjene svojstva drugog dijela (Glennan, 2002b: 344; usp. Skipper Jr. i Millstein, 2005: 339). Međutim, Glennanova ideja interakcije čija je posljedica promjena svojstva dijelova ne zahvaća dinamiku ili produktivni kontinuitet strukture kolektivne intencionalnosti. Naime, njegovo razumijevanje interakcije ne zahvaća načine na koje različitost unutar entiteta može utjecati na interakciju i kooperaciju. Kao i kod Glennana, MDC koncept nije ništa uspješniji u objašnjavanju produktivnog kontinuiteta mehanizma kolektivne intencionalnosti. Ovdje govorimo o entitetima i njihovim aktivnostima koje vrijede za produktivni kontinuitet mehanizma. Točnije, aktivnosti su generator promjena, a entiteti su ti koji su involvirani u te aktivnosti (Skipper Jr. i Millstein, 2005: 341). U slučaju kolektivne intencionalnosti entitete lako možemo identificirati, to su organizmi, individue. Međutim ono što ne možemo sa sigurnošću utvrditi kod MDC koncepta je koje su to relevantne aktivnosti. Radi li se o prihvaćanju, vjerovanju ili nečemu trećem? Stoga odbacujemo ideju da individue, entiteti, mogu služiti isključivo kao dijelovi koji tvore mehanizam kolektivne intencionalnosti. Drugim riječima, ni MDC ni Glennanov koncept mehanizma ne uspijevaju ponuditi odgovor na pitanje produktivnog kontinuiteta kolektivne intencionalnosti.

\section{Regularnost}

Do sada smo uočili kako kolektivna intencionalnost nije uspješno zahvaćena i okarakterizirana ni Glennanovim ni MDC konceptom mehanizma. U ovom ogledu nastojat ćemo istražiti je li kolektivna intencionalnost regularna na način koji iznose Glennan i MDC.

U prvom odjeljku o mehanicističkoj filozofiji vidjeli smo da Glennan brani određenu metodologiju za izgradnju vlastitog modela mehanizma. Pri tome tvrdi da su interakcije događaji promjene svojstva dijelova mehanizma, a te interakcije su određene direktnim, invarijantnim i o promjenama zavisnim generalizacijama (Glennan, 2002b: 344). Upravo su te generalizacije temelj regularnosti Glennanova modela mehanizma. Drugim riječima, kada Glennan tvrdi da je mehanizam solidan ili da je interakcija između dijelova mehanizma solidna, smatra da se te interakcije, odnosno ponašanje tih dijelova, ubraja u invarijantne generalizacije (Skipper Jr. i Millstein, 2005: 342). Suprotno tome, MDC smatraju da je mehanizam regularan utoliko ukoliko uvijek ili u većini slučajeva funkcionira na isti način u istim uvjetima (Machamer, et al., 2000: 3; Skipper Jr. i Millstein, 2005: 343). Pitanje koje se ovdje nameće je sljedeće: možemo li govoriti o regularnosti mehanizma kolektivne intencionalnosti? Premda se doima intuitivno primamljivo smatrati da bi kolektivna intencionalnost mogla biti adekvatno zahvaćena idejom stabilnog mehanizma, ovdje se tvrdi da se radi o probabilističkom fenomenu. Zamislimo sljedeći scenarij:

$» \mathrm{U}$ vagonu vlaka sjedi šestero međusobno nepovezanih/nasumičnih osoba. Svatko od njih bavi se svojim poslom, čita, gleda kroz prozor vagona, surfa na smartphoneu itd. Ni jedna od spomenutih osoba nije u međuvremenu uspostavila nikakav kontakt očima ni s jednim od spomenutih suputnika u vagonu. Dakle, polazimo od teze da ne tvore kolektivnu intencionalnost u ovom trenutku. Međutim, nakon nekog određenog vremena, jedan od njih/putnika kaže: 'Uf, ovdje je prevelika gužva!' U vagonu započinje generalni žamor, mrmljanje te svaki od spomenutih putnika kaže nešto poput 'Da, doista!'; 'Slažem se!'. U ovom trenutku ostvareno je kolektivno 
vjerovanje 'u ovom vagonu je prevelika gužva!' među šestero osoba.« (Gilbert i Pilchman, 2014: 203)

Rukovodimo li se ovim primjerom koji inicijalno koristi Gilbert, tada slijedi da skup ovih pojedinaca formira kolektivno vjerovanje $u$ onom trenutku kada ostvare kolektivno vjerovanje tj. zajedničku posvećenost (eng. joint commitment). Prema tome, ovih šestero ljudi posjeduje kolektivnu intencionalnost ako i samo ako je njihova centralna premisa vjerovanje »u ovom vagonu je prevelika gužva« (Gilbert i Pilchman, 2014: 203). Slijedi da, unatoč zamamnoj ideji kolektivne intencionalnosti kao mehanizma, valja biti oprezan $\mathrm{u}$ njegovoj deskripciji i atribuciji. Naime, premda sam fenomen kolektivne intencionalnosti ne uspijeva zadovoljiti prethodno zadane uvjete koje nalažu Glennanova ideja sistem mehanizma i MDC model, ne odbacujemo ideju da kolektivna intencionalnost ne posjeduje potencijal mehanizma. Prisjetimo li se Glennanove deskripcije mehanizma, uviđamo kako on uvodi jednu signifikantnu dihotomiju, naime on razlikuje proces-mehanizam i sistem-mehanizam.

»Proces-mehanizam označava jedinstveni lanac događaja koji je jedinstvena sekvenca mogućih međusobno povezanih događaja proizvoljne složenosti.« (Skipper Jr. i Millstein, 2005: 332)

Što je to točno dovelo do pojavnosti kolektivne intencionalnosti u primjeru s vagonom? U primjeru s vagonom to je jedan određeni događaj, joint commitment, odnosno formiranje kolektivnog vjerovanja »u ovom vagonu je previše ljudi« koje je rezultiralo pojavnošću kolektivne intencionalnosti, tj. kolektivnog djelovanja.

Iz spomenutog slijedi da, unatoč tome što nijedan od spomenuta dva temeljna koncepta nove mehanicističke filozofije ne uspijeva u potpunosti zahvatiti i opisati mehanicistički potencijal kolektivne intencionalnosti, ne odbacujemo ideju da ona to nije. Definiramo li kolektivnu intencionalnost kao mehanizam kroz prizmu središnjih pitanja koje kategoriziraju Glennanov koncept, točnije koncept sistem mehanizma i MDC koncept, očito je da je prigovor kako kolektivna intencionalnost nije mehanizam u potpunosti opravdan. Razlog tome leži u činjenici da su spomenuta dva koncepta prikladna za deskripciju stabilnih, repetitivnih mehanizama u biologiji, neurofiziologiji itd., ali ne i u epistemologiji, tj. za deskripciju prirode kolektivne intencionalnosti. Nadalje, ova dva koncepta sadrže prejake uvjete na koje kolektivna intencionalnost nije u stanju odgovoriti. Međutim, oslabimo li spomenute uvjete, uvidjet ćemo da kolektivna intencionalnost, tj. collective agency posjeduje elemente mehanizma i kao takav može ponuditi novu dimenziju epistemološkog razumijevanja ovog fenomena. U protivnom, odbacimo li ideju kolektivne intencionalnosti kao mehanizma, nije posve jasno i razumljivo što bi ono moglo biti. Posljedično, generiramo brojne diskusije na tu temu, konstruiramo tvrdnje o potrebitosti formiranja nove, generičke epistemologije (Gilbert i Pilchman, 2014: 209) pod pretpostavkom da će nam možda to omogućiti jasniji uvid i razumijevanje kolektivne intencionalnosti. Nadalje, unatoč superiornosti mehanizama i mehanicističkog objašnjavanja zakona i nomološkog objašnjenja, evidentno je da se brojni događaji ne pojavljuju kao posljedica operacije stabilnih mehanizama (Glennan, 2010: 251). Štoviše, kolektivna intencionalnost posjeduje natruhe takvog mehanizma.

Zaključno možemo ustvrditi da kolektivna intencionalnost posjeduje potencijal mehanizma, međutim, da bismo ga uspjeli adekvatno zahvatiti i opisati moramo oslabjeti zahtjeve koje postavljaju Glennanov sistem-mehanizam i 
MDC koncept. Kao potencijalni kandidat ističe se Glennanova prvotna ideja proces-mehanizma (Glennan, 2002a: 128, Glennan, 2002b: 344, Skipper Jr. i Millstein, 2005: 332). Prema tome, da bismo opisali mehanizam kolektivne intencionalnosti trebamo pronaći uzročni spoj u kojemu jedan određeni događaj može uzrokovati drugi određeni događaj, tj. kolektivnu intencionalnost. U slučaju kolektivnog djelovanja to je kolektivno vjerovanje, tj. joint commitment. Nadalje, ovaj rad nastoji istražiti na koji bi način epistemološko poimanje kolektivne intencionalnosti moglo biti integrirano u strukturu mehanizma. Ova istraga sugerira da su koncept sistem mehanizma i MDC koncept nedovoljno rafinirani da zahvate i objasne provenijenciju kolektivne intencionalnosti u epistemološkom pogledu. Stoga, da bismo mogli razumjeti i uvidjeti posjeduje li kolektivna intencionalnost mehanicistički potencijal moramo tražiti mehanicistički model koji je u stanju zahvatiti uzročnost probabilističkih relacija, a kao dobar kandidat te deskripcije ističe se ideja proces mehanizma.

\section{Zaključak}

Ovaj ogled ne nastoji pružiti konačan odgovor na pitanje kolektive intencionalnosti, nego nastoji istražiti posjeduje li kolektivna intencionalnost potencijal mehanizma te može li biti okarakterizirana okvirom nove mehanicističke filozofije. No pitanje kojim se valja prethodno pozabaviti jest pitanje prirode kolektivne intencionalnosti. Stoga se u početnom dijelu rada značajan dio posvećuje socio-ontološkoj analizi kolektivne intencionalnosti i njezinoj alternativi, epistemološkoj analizi. Za joint commitment vrijedi da »članovi populacije $\mathrm{P}$, kolektivno vjeruju da $\mathrm{P}$ ako i samo ako su se zajednički posvetili tome da kao tijelo vjeruju da P« (Gilbert i Pilchman, 2014: 197). Drugim riječima, kolektivna intencionalnost predstavlja fenomen kolektivnog vjerovanja. Međutim, prije nego što se okrenemo mehanicističkoj reprezentaciji kolektivne intencionalnosti, valja ukazati na to da, unatoč suprotstavljenim stajalištima Johna Searlea i Margaret Gilbert, možemo uočiti dvije važne točke slaganja obratimo li veću pozornost na njihovu terminologiju. Kao prvo, Searle pojmi kolektivno vjerovanje kao rudimentaran fenomen koji nije nužno uvjetovan i svediv na individualna vjerovanja te tako napušta redukcionističku analizu kolektivne intencionalnosti. Epistemološka alternativa koju iznosi Gilbert jednako tako odbacuje ovo viđenje. Drugo, i Gilbert i Searle smatraju da je sumativizam neodrživ i neprihvatljiv za objašnjavanje kolektivnog vjerovanja. Ono u čemu se ne slažu je prihvaćanje postojanja pluralnog subjekta. Naime, za Gilbert to je više nego moguće, međutim Searle odbacuje ovu ideju te smatra kako je pojedinac osnovni tvorbeni element kolektivne intencionalnosti. Time završavam studiju socio-ontološke i epistemološke analize prirode kolektivne intencionalnosti. Povrh toga, valja naglasiti kako obje pozicije ističu vlastitu dijalektičku defanzivnost i reaktivno držanje. U nastavku rada okrećemo se ideji detekcije i deskripcije mehanicističkog potencijala kolektivne intencionalnosti. Prema tome, nit vodilja ovog rada nije pružanje uniformnog odgovora na pitanje kolektivne intencionalnosti, već nastojanje da se istraži možemo li govoriti o kolektivnoj intencionalnosti kao mehanizmu. Stoga je centralno pitanje ovog rada: predstavlja li kolektivna intencionalnost mehanizam? Takvo nas promišljanje dovodi do temeljnog promišljanja nove mehanicističke filozofije i njezine interpretacije mehanizma.

Kada govorimo o novoj mehanicističkoj filozofiji, to podrazumijeva dvije osnovne sheme mehanicističke reprezentacije, Glennanovu koncepciju me- 
hanizma i onu Machamera, Dardena i Cravera (MDC) (Skipper Jr. i Millstein, 2005: 331-334). Unatoč primamljivoj ideji koju nudi nova mehanicistička filozofija, uviđamo kako ni jedan od spomenuta dva centralna tabora nove mehanicističke filozofije, Glennanov koncept mehanizma i MDC koncept mehanizma, ne uspijevaju adekvatno zahvatiti i opisati kolektivnu intencionalnost, koristeći pri tome vlastitu shemu mehanicističke reprezentacije. Naime, analiza kolektivne intencionalnosti kroz prizmu MDC i Glennanova koncepta apostrofira tri ključna aspekta na koji oni ne uspijevaju odgovoriti, tj. pitanje organizacije, produktivnog kontinuiteta i regularnosti. Unatoč tome što ni jedan od spomenuta dva tabora nove mehanicističke filozofije ne nudi plauzibilno rješenje i odgovor na pitanje egzistencije mehanicističkog potencijala kolektivne intencionalnosti, ne odbacujem ideju kolektivne intencionalnosti kao mehanizma. Štoviše, zadržavam stajalište da spomenuta dva koncepta nove mehanicističke filozofije posjeduju prejake uvjete, a samim time su nedovoljno rafinirani da zahvate mehanizme poput kolektivne intencionalnosti. Alternativa koja se u radu nudi je slabljenje kriterija mehanizama, a kao idealan kandidat iskače Glennanova ideja proces mehanizma. Stoga, zaključujem da kolektivna intencionalnost posjeduje potencijal mehanizma.

\section{Popis literature}

Brunnander, B. (2007): »What is Natural Selection?«, Biology and Philosophy 22 (2006) 2, str. 231-246. doi: https://doi.org/10.1007/s10539-005-9008-4.

Cohen, J. L. (1995): An Essay on Belief and Acceptance. Oxford: Clarendon Press.

Darden, L.; Craver, C. (2002): »Strategies in the interfield discovery of the mechanism of protein synthesis «, Studies in History and Philosophy of Science Part C: Studies in History and Philosophy of Biological and Biomedical Sciences 33 (2002) 1, str. 1-28. doi: https:// doi.org/10.1016/s1369-8486(01)00021-8.

Ferraris, M. (2015): »Collective intentionality or documentality? «, Philosophy and Social Criticism 41(2015) 4-5, str. 423-433. doi: https://doi.org/10.1177/0191453715577741.

Gilbert, M. (2002): »Belief and Acceptance as Features of Groups«, ProtoSociology 16 (2002), str. 35-69. doi: https://doi.org/10.5840/protosociology20021620.

Gilbert, M.; Pilchman, D. (2014): »Belief, Acceptance, and What Happens in Groups: Some Methodological Considerations«, u: Jennifer Lackey (ur.), Essays in Collective Epistemology, Oxford: Oxford University Press, str. 189-212. doi: https://doi.org/10.1093/ acprof:oso/9780199665792.003.0009.

Glennan, S. (1996): »Mechanisms and the nature of causation«, Erkenntnis 44 (1996) 1, str. 49-71. doi: https://doi.org/10.1007/bf00172853.

Glennan, S. (2002a): »Contextual unanimity and the units of selection«, Philosophy of Science 69 (2002) 1, str. 118-137. doi: https://doi.org/10.1086/338944.

Glennan, S. (2002b): »Rethinking mechanistic explanation«, Philosophy of Science 69 (2002) S3, str. 342-353. doi: https://doi.org/10.1086/341857.

Glennan, S. (2010): »Ephemeral Mechanisms and Historical Explanation«, Erkenntnis 72 (2010) 2, str. 251-266. doi: https://doi.org/10.1007/s10670-009-9203-9.

Machamer, P.; Darden, L.; Craver, C. (2000): »Thinking about mechanisms«, Philosophy of Science 67 (2002) 1, str. 1-25. doi: https://doi.org/10.1086/392759.

Matthews, L. J. (2016): »On closing the gap between philosophical concepts and their usage in scientific practice: A lesson from the debate about natural selection as mechanism«, Studies in History and Philosophy of Science Part C: Studies in History and Philosophy of Biological and Biomedical Sciences 55 (2016), str. 21-28. doi: https://doi.org/10.1016/ j.shpsc.2015.11.012. 
Meijers, A. W. M. (1999): Belief, Cognition and the Will, Tilburg: Tilburg University Press.

Searle, J. R. (2010): Making the Social World: The Structure of Human Civilization, New York: Oxford University Press. doi: https://doi.org/10.1093/acprof:osobl/9780195396171.001.0001.

Searl, J. R. (1995): The Construction of Social Reality, New York: The Free Press.

Skipper Jr., R. A.; Millstein, R. L. (2005): »Thinking about evolutionary mechanisms: natural selection «, Studies in History and Philosophy of Science Part C: Studies in History and Philosophy of Biological and Biomedical Sciences 32 (2005) 2, str. 327-347. doi: https://doi.org/10.1016/j.shpsc.2005.03.006.

Stevenson, L. (2002): »Six Levels of Mentality«, Philosophical Explorations 5 (2002) 2, str. 105-124. doi: https://doi.org/10.1080/10002002058538725.

Toumela, R. (2000): »Belief Versus Acceptance«, Philosophical Explorations 3 (2000) 2, str. 122-137. doi: https://doi.org/10.1080/10002002058538725.

Wray, B. K. (2001): »Collective Belief and Acceptance«, Synthese 129 (2001) 3, str. 319333. doi: https://doi.org/10.1023/a:1013148515033.

\title{
Matija Lukač
}

\section{Thinking about Collective Intentionality as a Mechanism}

\begin{abstract}
The papers aim is to investigate if collective intentionality is potentially a mechanism and can it be characterised by one of the two fundamental approaches to the mechanism, by Glennan's concept and/or MDC concept. The paper does not offer an answer to the debate on the nature of collective intentionality, but instead, it attempts to underline what philosophers may learn from $i t$. The reading and interpretation in this paper are not entirely similar to Cohen's understanding of intentionality. While Cohen believes that collective intentionality is altogether reducible to individual intentionality, this paper is more of an epistemological question regarding the right way of defining collective intentionality as a mechanism. The first part of the paper refers to determining the role of the very debate on collective intentionality. Epistemological and socioontological positions in role-defining the collective intentionality is considered, along with its explanation, method of research, and the argument that both analysis encounters similar problems (irreducibility of collective intentionality to individual intentionality). In the second part of the paper, I examine the role of this debate and what can we learn from it. More correctly, I intend to explore does collective intentionality has the potential of mechanisms, that is, can it be characterised as a mechanism if we guide ourselves with the concept of mechanism developed in contemporary philosophy of mechanism.
\end{abstract}

\section{Key words}

Laurence Jonathan Cohen, intentionality, collective intentionality, mechanism, new mechanistic philosophy 